\title{
SURFACE WATER QUALITY ASSESSMENT IN SEMI-ARID REGION (EL HODNA WATERSHED, ALGERIA) BASED ON WATER QUALITY INDEX (WQI)
}

\author{
AMEL FERAHTIA a,b MOHAMMED TAHAR HALILAT ${ }^{c}$, \\ FATEH MIMECHE ${ }^{\mathrm{d} *}$, ETTAYIB BENSACl ${ }^{\mathrm{a}, \mathrm{b}}$
}

\begin{abstract}
The present study was aimed to assess the surface water pollution sources in a semiarid region of Algeria by characterizing the physicochemical quality of the water of the main Wadis of the El Hodna watershed and determining the water quality index according to the uses of drinking water, irrigation, and aquatic life. This index is calculated in purpose to communicate information on the water quality for concerned citizens and policymakers. The calculated WQI values of the studied Wadis were higher than 100, which indicates that the waters of the El Hodna watershed are unfit for human consumption, irrigation, and aquatic life. The obtained results have shown that different types of pollution (industrial, domestic and agricultural) affect the waters of the El Hodna watershed, which lead to degrade the water quality of this aquatic ecosystem and consequently its biodiversity and public health.
\end{abstract}

Keywords: Water quality index, surface water quality, El Hodna watershed, Pollution, semiarid region, Algeria.

\section{INTRODUCTION}

Water is a natural resource, and it forms the principal component of all living organisms in this world [1], which plays a massive role in different vital and structural activities. It is familiar that water is an essential source for industrial development, irrigation, hydroelectric production, drinking purposes, and domestic uses for human survival [2].

\footnotetext{
a Department of Natural and Life Sciences, Faculty of Sciences, M'Sila University, M'Sila 28000, Algeria

${ }^{b}$ Biology, Water and Environment Laboratory (LBEE), University 8 Mai 1945 Guelma, BP 401, Guelma, 24000, Algeria

c Faculty of Natural and Life Sciences, University of KasdiMerbah, 30000, Ouargla, Algeria

d Department of Agricultural Sciences, M'Sila University, M'Sila, 28000, Algeria,

* Corresponding author: fateh.mimeche@univ-msila.dz
} 
The requirement for water increased due to the expansion of agriculture and industry, urbanization, and the increase in the population demographic. In many countries, people depend on piped water supplied from reservoirs as well as private wells for their water needs [3]. Therefore, with an increased understanding of the importance of drinking water quality to public health and raw water quality to aquatic life, there is a great need to assess surface water quality [4].

Water quality indicates the relation of all hydrological properties including physical, chemical and biological characteristics of the water body. Hence, water quality assessment involves the analysis of physicochemical and biological parameters that reflect the biotic and abiotic status of the aquatic ecosystem [5]. The abundance of particular element might suggest the unstable or unfavorable ecosystem which can have a negative or positive impact on the population [6].

Many approaches have been applied to assess the water chemistry and status of the water quality in the river. The water indexes are the most effective tools to convey information about water quality to communities of users, those responsible for the management, decision-making authorities, and the public [7].The water quality index (WQI) can tell us whether the overall quality of water bodies possesses a potential threat to various uses of water, such as habitat for aquatic life, irrigation water for agriculture and livestock, recreation, esthetics, and drinking water supplies [8].WQI can reduce the bulk of the information into a single value to express the data in a simplified and logical form, it takes information from several sources and combines them to develop an overall status of a water system [1]. Many studies around the world have been using the WQI to survey the evolution of the surface water quality as well as in India [9], Benin [10], Nigeria [11], Turkey [12] and Egypt [13].

In Algeria, most studies have focused on the effects of industrial and urban discharges on surface water quality like [14], [15], [16], [17], [18] and [19]. The watershed of the El Hodna, with its large area located in a semiarid region, its passage between the Tellian domain to the north and the Sahara to the south, promotes the diversity of bioclimatic environments that strongly influences the socioeconomic activity of these regions. This study area is highly influenced by human pressure resulting to domestic, agricultural, and partially industrial activities. In the aim to improve our knowledge on the water pollution resources of the El Hodna watershed, we tried to characterize the physicochemical quality and determine the WQI of the main Wadis of this watershed to verify their ability for consumption, their use in agriculture irrigation and for aquatic life referring to acceptable norms. 


\section{RESULTS AND DISCUSSION}

\section{Surface water properties}

Table 1 shows the physico-chemical parameters per Wadi with the mean, standard deviation (SD), minimum and maximum.

The spatial differences between the TS, Salinity, Turbidity, $\mathrm{NO}_{3}{ }^{-}, \mathrm{NO}_{2}$, $\mathrm{Cl}^{-}$and $\mathrm{SO}_{4}{ }^{2-}$ variables were significant $(\mathrm{p}<0.05)$. No spatial differences were observed for the remaining of the physicochemical parameters.

The surface water temperature ranged between $\left(12.5 \mathrm{C}^{\circ}-27 \mathrm{C}^{\circ}\right)$ at all the nine studied Wadis (Table 1$)$. The minimum value $\left(12.5 \mathrm{C}^{\circ}\right)$ was observed in Wadi El Ham (01) and the maximum value $\left(27 \mathrm{C}^{\circ}\right)$ was observed in Wadi Khobana. The temperature modified by the climatic conditions, the sampling time humidity, and sunlight exposure [20].

The recorded values of electrical conductivity were shown notable variations from Wadi to another. The maximum value of $7767.36 \mu \mathrm{S} / \mathrm{cm}$ was recorded in Wadi El ham (01). According to [21] the high conductivity could be interpreted by domestic and industrial effluent discharges transport a lot of dissolved conducting minerals into the water bodies. The minimum value of $786 \mu \mathrm{S} / \mathrm{cm}$ was recorded in Wadi Lougmen, this can be explained to the dilution of the water by the addition of rainwater [22]. Important changes in conductivity can be an indicator that some other source of pollution has entered the stream [23].

The $\mathrm{pH}$ of the water samples ranged between 6.56 to 8.90 , these values were found to be nearly neutral or alkaline, which characterize the calcareous soils of the El Hodna region. The minimum value of 6.56 was observed in Wadi El Khobana and the maximum value of 8.90 was found in Wadi Bousâada. The increase in the $\mathrm{pH}$ could be related to the photosynthesis and the growth of aquatic plants, where the photosynthesis consumes $\mathrm{CO}_{2}$ and leads to a raising in the $\mathrm{pH}$ values [13].

The Dissolved oxygen concentration results varied from one station to another, depending on the nature of the microclimatic conditions and pollution extent. Almost all the water samples collected from the Wadis had considerably low DO values. The maximum value was recorded in Wad M'cif $(7.34 \mathrm{mg} / \mathrm{l})$, and the minimum value was noted in Wadi Bousâada $(1.25 \mathrm{mg} / \mathrm{l})$. The lowest concentrations were due to the additional discharge of sewage and other waste combined with the microbial decomposition of the organic matter [17]. 


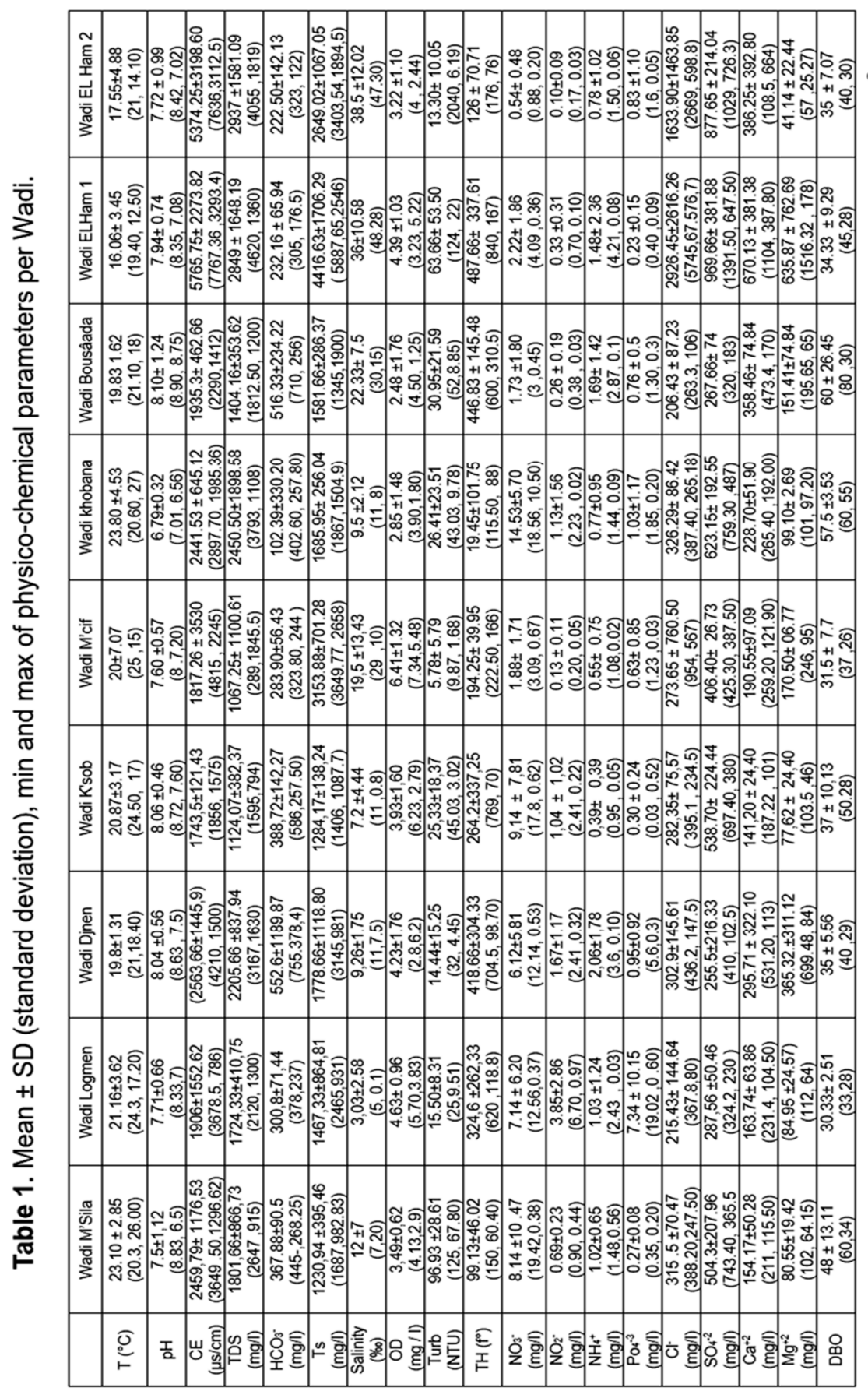


The properties of the TDS, TS and salinity of all the studied samples were ranged between 289- $4620 \mathrm{mg} / \mathrm{l}, 931-5887.65 \mathrm{mg} / \mathrm{l}$ and $0.1-48 \%$ o respectively. The highest concentrations of these parameters were found in Wadi El Ham (01) (Table 1). The lowest TDS was found in Wadi M'cif (289 mg/l), while the lowest TS and salinity were found respectively in Wadi Lougmen (931 mg/l, 0.1\%o). The ecological imbalance in the aquatic ecosystem caused by the technical abrasive action of total solids [24]. The excess of dissolved solids affects the water quality for all its uses; drinking, agricultural and industrial purposes. Many problems caused by high concentrations of TDS like a bad odor and taste, hardness, corrosion, and scaling in the water supply system [23]. Salinity, TS, and TDS augmentation are original to the effluent discharges from several industrial establishments around the El Hodna basin, also they are due to the domestic activities, lithologic composition, and evaporation effects under the arid climate of this region, which can promote the concentration of salts in water.

The turbidity values in the present study are exhibited between (1.68125 NTU). The maximum value was observed at Wadi M'Sila (125 NTU) and the minimum value was reported in Wadi M'cif (1.68 NTU). The high turbidity in M'Sila Wadi may be explained by the discharge of the wastewater and the waste construction materials, because it crosses several urban agglomerations and industrial zones of M'Sila. The high turbidity causes reduced transparency of water due to the presence of particles such as clay or silt, finely divided organic matter, plankton, or other microscopic organisms [20]. Besides, raised values of turbidity lowering the biological productivity of aquatic organisms [25].

The total hardness from the water samples are ranged between 60.40 $f^{\circ}$ and $840 f^{\circ}$. The lowest amount of total hardness was recorded in Wadi M'Sila, this decreaseis due to the low concentration of calcium and magnesium [10], while the highest total hardness was recorded in Wadi El Ham (01) due to the addition of large quantities of urban sewage discharged in this Wadi [26]. According to [27] the variation of the total hardness in the water can be related to the nature of the soil traversed.

The chloride values are high almost in all the studied Wadis, the minimum value was recorded in Wadi Lougmen $(80 \mathrm{mg} / \mathrm{l})$ and the maximum value $(5745.67 \mathrm{mg} / \mathrm{l})$ was recorded in Wadi EL Ham (01). The high chloride concentration is due may be to the disposal of sewage water of Baniou city in this Wadi. Human and other animals release a very high quantity of chloride together with nitrogenous compound (urine and feces) [2]. The concentration of these chemical element considered an important parameter for the detection of contamination by the domestic sewage [28-29]. 
The phosphate values in the present study were ranged between 19.02 to $0.03 \mathrm{mg} / \mathrm{l}$, where the minimum values were observed at Wadi M'cif, and the maximum values were noted at Wadi Lougmen, due probably to the augmentation of pollution loaded by organic matter and agricultural runoff around this station. Phosphate is one of the limiting nutrients causing the eutrophisation [30]. The major sources of phosphate in the water are domestic sewage, agriculture effluents, and industrial wastewaters. Thus, the high concentration of phosphate considered as a pollution indicator [31].

The concentration of sulphate in the present investigation varied from 102.5 to $1391.5 \mathrm{mg} / \mathrm{l}$. All the stations reported high concentrations of sulphate. The minimum concentration was recorded in Wadi Djnen $(102.5 \mathrm{mg} / \mathrm{l})$ and the maximum concentration was recorded in Wadi El Ham (01) $(1391.5 \mathrm{mg} / \mathrm{l})$. These high levels of sulphates are due to wastewater and domestic discharges. Sulphates come from run-off, fertilizers containing relatively large amounts of organic and inorganic sulfur compounds, $\mathrm{SO}_{4}{ }^{-2}$ ions in water under natural conditions [32].

The values of bicarbonate fluctuated between 122 and $755 \mathrm{mg} / \mathrm{l}$. The maximum value was found in Wadi Djnen, and the minimum value was observed in Wadi El Ham (02). The highest bicarbonate concentration in Wadi Djnen was explained by the evacuation of domestic effluents and solid waste, which attributed to the presence of a large amount of organic matter accessible to bacterial decomposition [33], during which $\mathrm{CO}_{2}$ is liberated and dissolves in water and accelerates the formation of $\mathrm{HCO}_{3}-[34]$.

The nitrate varied between $0.2 \mathrm{mg} / \mathrm{l}$ in Wadi EL Ham (2) and $19.41 \mathrm{mg} / \mathrm{l}$ in Wadi M'Sila. The higher concentration of $\mathrm{No}_{3}{ }_{3}$ maybe due to the influx of nitrogen in the floodwater and the discharge of domestic, industrial wastewaters and runoff from agricultural fields settled across the El Hodna watershed, which can lead to excessive proliferation of algae in the water body and can lead to eutrophication of the environment [35].

However, the nitrite was relatively low, except Wadi Lougmen, which marked a high value $(6.7 \mathrm{mg} / \mathrm{I})$ that could be explained by the incomplete oxidation of organic matter, particularly in summer denitrifying bacteria break up nitrates into nitrites and ammonia. Nitrite in water bodies is derived essentially from industrial waste and domestic waste [36].

Ammonium levels ranged between $0.02 \mathrm{mg} / \mathrm{l}$ and $4.21 \mathrm{mg} / \mathrm{l}$. The low concentrations of ammonium in all Wadis can be explained by the transformation of the ammonium in nitrate by the nitrifying bacteria, also by the assimilation of the ammonium ion by the aquatic plants [37]. Generally, it comes from the biodegradation of waste and inputs from domestic, agricultural and industrial [38]. The presence of $\mathrm{NH}_{4}{ }^{+}$with high concentrations in a stream or a lake can result in algae blooming and eventually the destruction of the aquatic ecosystem [39]. 
The minimum of the Calcium concentration was registered in Wadi El K'sob (101 mg/l) and the maximum value is in Wadi El Ham (01) $(1104 \mathrm{mg} / \mathrm{l})$. Calcium is responsible for contaminating the water, where the disposal sewage of industrial waste is considered an important source of calcium [2].

The minimum value of Magnesium concentration is $25.27 \mathrm{mg} / \mathrm{I}$ in Wadi El Ham (02), while the maximum value recorded at Wadi El Ham (01) (1516.32 $\mathrm{mg} / \mathrm{l})$, it might be due to the illegal elimination of domestic and industrial wastewater [40] in this Wadi. The high magnesium values can be toxic to aquatic life [37].

Biochemical oxygen demand (BOD) is used to determine the level of organic pollution of the water. The BOD recorded from all the nine Wadis ranged between (26 - $80 \mathrm{mg} / \mathrm{l})$. The highest BOD value was observed at Wadi Bousaada, and the lowest was in Wadi M'cif. This increase of BOD5 in Wadi Bousaada is due to disposal of domestic, industrial effluents, and slaughterhouse operations, it is the most commonly used parameter for determining the oxygen demand on receiving water of a municipal and industrial discharge [40]. The higher the amount of BOD, the higher will be the amount of pollution in the water [41].

\section{Relationships between water physicochemical parameters}

The Pearson correlation matrix obtained from our study for each parameter is showed in the (Table 2). The temperature showed positive correlation with $\mathrm{NO}_{3}{ }^{-}(\mathrm{r}=0.743)$. While the $\mathrm{pH}$ showed positive correlation with $\mathrm{HCO}_{3}{ }^{-}(r=0.782)$ and $\mathrm{TH}(r=0.690)$. Positive correlations observed between conductivity and salinity, TDS, TS Cl- $\mathrm{Ca}^{+2}$ and $\mathrm{So}_{4}{ }^{2}(\mathrm{r}$ between 0.703 and 0.945 ). It can be seen that TDS,TS and salinity are positively correlated with each other and with the minerals $\mathrm{Cl}^{-}, \mathrm{SO}_{4}{ }^{+2}, \mathrm{Ca}^{+2}$ and $\mathrm{Mg}^{+2}$, also the concentration of chloride has a significant positive relation with $\mathrm{So}_{4}{ }^{2-}$, $\mathrm{Ca}^{+2}, \mathrm{Mg}^{+2}$, this, indicates a large presence of inorganic dissolved solids due either to human influences or to the geological nature of the terrain crossed. However, the strong positive correlation of calcium with $\mathrm{Mg}^{2+}(r=0.827)$ may be indicate the common origin [42].

The results of the Principal Component Analysis reveal that the first two axes account for $57.45 \%$ of the variability in the influence of physicochemical parameters on the sites. The $\mathrm{F} 1$ axis has a variance of $37.52 \%$ and the $\mathrm{F} 2$ axis has $19.93 \%$. Based on PCA, three groups were identified: 1, 2, and 3. The factorial axes shows that the group 1 (cluster 1) formed by the site of Wadi EL Ham 1, Wadi EL Ham 2 and Wadi Djnen (Figure 1). 


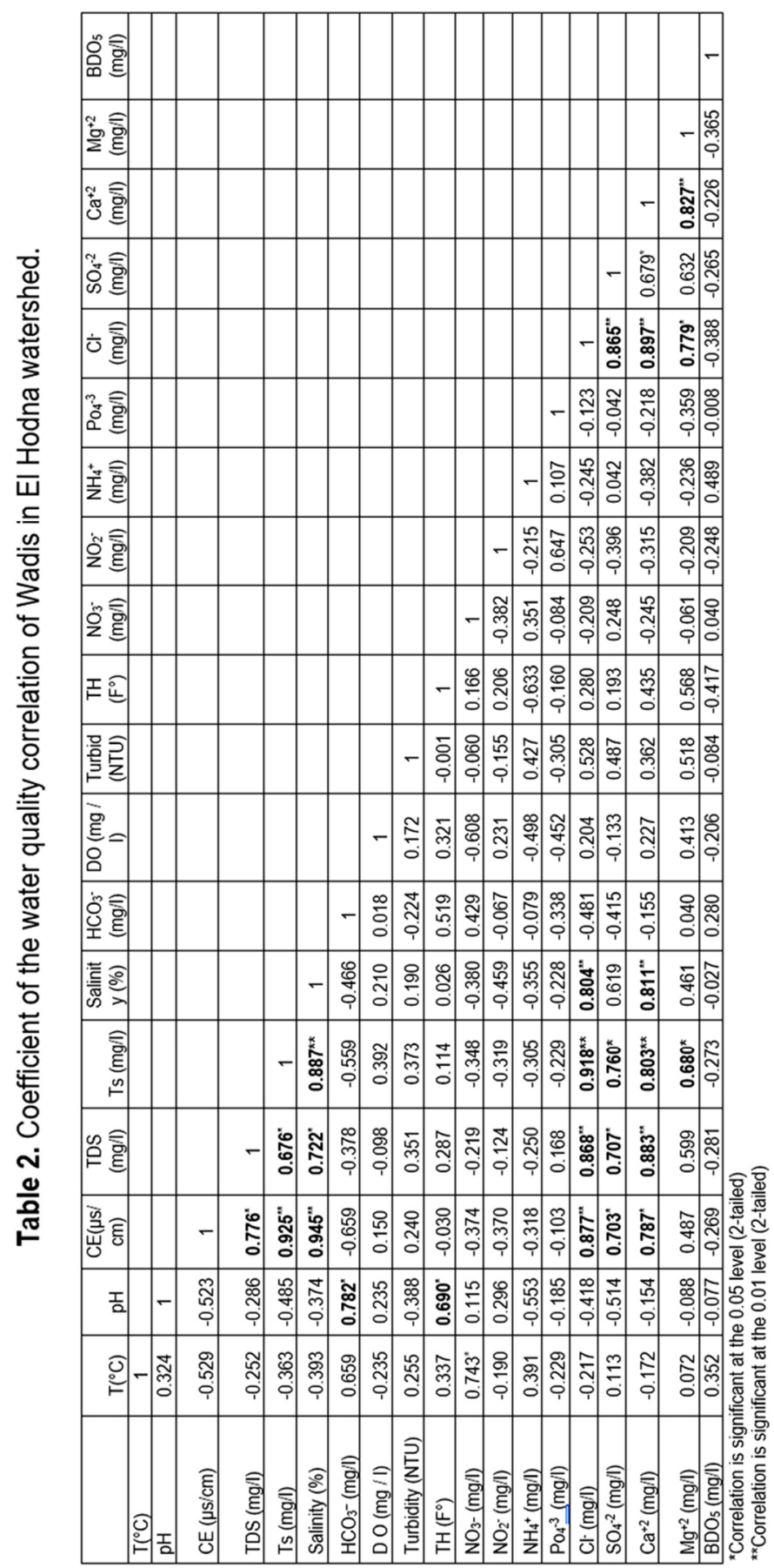


Thus cluster record high values of turbidity, $\mathrm{HCO}_{-3}, \mathrm{SO}_{4}^{-2}$, TDS, TS, $\mathrm{Cl}^{-}$, $\mathrm{Ca}^{2+}, \mathrm{Mg}^{+2}, \mathrm{CE}, \mathrm{pH}$ and $\mathrm{NH}^{+4}$. This shows an inorganic pollution in the water related to the domestic activities in these stations. The $\mathrm{BDO}_{5}, \mathrm{NO}_{3}$ and temperature are located on the same side of the (cluster 2) formed from the following sites: Wadi M'Sila, Wadi khobana, Wadi Bousaada which shows an urban, industrial and agricultural organic pollution. Therefore, the sites: Wadi M'cif, Wadi K'sob, Wadi EL Khobana (cluster 3) have high values of $\mathrm{NO}^{-}$, $\mathrm{PO}_{4}^{-}$associated with the impacts of agricultural activities (leaching of fertilizers) in the areas surrounding these Wadis.

${ }^{*}$ Correlation is significant at the 0.05 level (2-tailed)

${ }^{* *}$ Correlation is significant at the 0.01 level (2-tailed)

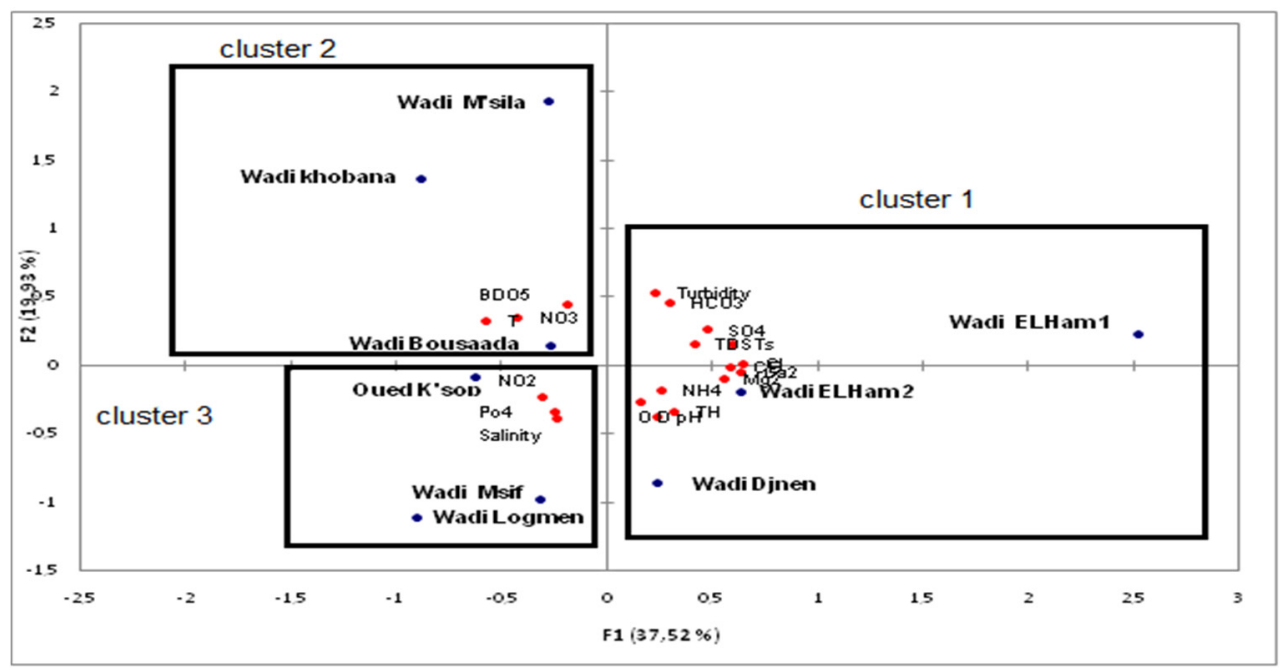

Figure 1. Projection of physico-chemical parameters on the factorial planes axes 1 and 2 , with the stations and groups.

\section{Water quality index}

The Water Quality Index (WQI) gives the overall quality of water based on large number of physico-chemical characteristics of water [43].

Table 03 illustrate the values of the WQI of the studied Wadis that flow in across the El Hodna basin and dump at the chott El Hodna. The WQI score for Drinking water was calculated using guidelines of [44] and [45] for irrigation water. While, aquatic life index was calculated using CCME guideline [46]. Only 09, 10 and 8 variables were used for the calculation of WQI according to Dinking, irrigation and aquatic life criteria respectively.

The selected parameters for drinking water are TDS, $\mathrm{pH}, \mathrm{NO}_{2}^{-}, \mathrm{NO}_{3}{ }^{-}$, $\mathrm{Cl}^{-}, \mathrm{SO}_{4}^{-2}, \mathrm{Ca}^{+2}, \mathrm{PO}^{-3} 4 \mathrm{Mg}^{+2}$. However, TDS, $\mathrm{pH}, \mathrm{CE}, \mathrm{NO}_{3}^{-}, \mathrm{PO}^{-3}, \mathrm{HCO}_{3}, \mathrm{Cl}^{-}$, 
$\mathrm{SO}_{4}^{-2}, \mathrm{Ca}^{+2}$ and $\mathrm{Mg}^{+2}$ were selected for irrigation. The selected variables for Aquatic life are T, TDS, $\mathrm{pH}, \mathrm{DO}, \mathrm{BOD}_{5}, \mathrm{NO}_{2}^{-}, \mathrm{NO}_{3}{ }^{-}$and $\mathrm{Cl}^{-}$.

The calculated WQI values for the studied Wadis ranged between 23.7- 633.95 for the drinking water, 6.30-97.72 for the irrigation water and 18.09-10616.35 for the aquatic life guidelines (Table 3 ).

Table 3. WQI and its categorization of different Wadis of El Hodna basin for drinking, irrigation, and aquatic life utilization.

\begin{tabular}{|c|c|c|c|c|c|c|}
\hline WADIS & $\begin{array}{c}\text { WOI } \\
\text { Irrigation }\end{array}$ & WQR & $\begin{array}{c}\text { WQI } \\
\text { Aquatic } \\
\text { life }\end{array}$ & WQR & WQI DW & WQR \\
\hline Wadi M'Sila & 18.06 & excellent & 712.6 & unfit & 146.45 & unfit \\
\hline Wadi Lougmen & 97.72 & $\begin{array}{c}\text { very } \\
\text { poor }\end{array}$ & 10616.35 & unfit & 633.95 & unfit \\
\hline Wadi K'sob & 55.35 & poor & 18.09 & excellent & 349.02 & unfit \\
\hline Wadi M'cif & 6.30 & excellent & 327.08 & unfit & 23.27 & excellent \\
\hline $\begin{array}{c}\text { Wadi EL } \\
\text { Khobana }\end{array}$ & 83.86 & $\begin{array}{c}\text { very } \\
\text { poor }\end{array}$ & 53.79 & poor & 557.12 & unfit \\
\hline Wadi Bousaada & 31.16 & good & 79.95 & $\begin{array}{c}\text { very } \\
\text { poor }\end{array}$ & 124.82 & unfit \\
\hline Wadi EL Ham 1 & 28.592 & good & 171.36 & unfit & 159.29 & unfit \\
\hline Wadi EL Ham 2 & 59.38 & poor & 280.87 & unfit & 339.35 & unfit \\
\hline WadiDjnen & 39.45 & good & 52.63 & unfit & 172.13 & unfit \\
\hline
\end{tabular}

WQI: water quality index. WQR: water quality rating.

Our study indicates that the fluctuation of the water quality index varied from excellent to very poor for water irrigation utilizations, where the highest value of WQI was registered at Wadi Lougmen (97.72), Wadi K'sob (55.35), Wadi Khobana (83.86) and Wadi El Ham (01) (59.38) which indicate poor and very poor water quality.

Based on WQI values, the water quality categorized from very poor to unfit for aquatic life guidelines. However, the water at Wadi K'sob was found excellent. Although, as recommendations on drinking water, except Wadi M'cif (23.27; excellent), all the other Wadis have unfit quality, with a quality index greater than 100 , that make them inappropriate for any domestic purposes. $\mathrm{A}$ high concentration of EC, TDS, $\mathrm{HCO}_{3}, \mathrm{Cl}^{-}, \mathrm{DBO}_{5}, \mathrm{PO}_{4}^{-3}, \mathrm{NO}_{3}^{-}, \mathrm{NO}_{2}^{-}, \mathrm{Cl}^{-}$and $\mathrm{SO}_{4}{ }^{2}$ could explain the high values of the water quality index (WQI) in these Wadis. The results of our study also indicate a large pollution load in the Wadis of the El Hodna basin. The high WQI values are contributed mainly by various 
anthropogenic activities such as discharge of untreated wastewater, sewage water, industrial effluents and agricultural runoff lead by many Wadis. Hence, our study concludes that the continuous pollution of the water sources by the human activities can lead to the degradation of the surface water quality (Chott El Hodna) and the ground water of this basin which considered the main water supply of the population of this semi-arid region.

\section{CONCLUSIONS}

The evaluation of the physicochemical quality of the water of the El Hodna basin Wadis that discharge in Chott El Hodna has allowed us to identify the pollution sources and the degree of contamination that affects this wetland of international importance. Overall, the obtained results revealed that most water quality parameters exceeding acceptable limits.

The direct discharge of urban waste and sewage water in the Wadis of the El Hodna basin and the intensive use of fertilizers in agriculture along the watershed make these waters very vulnerable to pollution and consequently the degradation of these waters, which leads to the loss of biodiversity of these aquatic ecosystems. Although, the results of the WQI show that the quality of the water of the different studied Wadis changed from excellent to very poor for irrigation, poor to unfit for consumption for aquatic life, except Wadi K'sob (excellent), and unfit for the human consumption for drinking water except Wadi M'cif (excellent). The value of the WQI indicates the extent of pollution when the domestic discharges and the agricultural activities constituted the major threat to the water quality of these Wadis. In order to preserve the water quality (surface and groundwater) of the EI Hodna basin against further degradation effective pollution monitoring should be taken shortly.

For this purpose, strict precautions should be taken along these Wadis and within the El Hodna basin to ensure safe human activities. Also, regular monitoringof the water quality of these Wadis and takes into account all protection measures by the concerned members and the local authorities.

\section{EXPERIMENTAL SECTION}

\section{Study Area}

The Hodna basin is with a drainage area of $26000 \mathrm{~km}^{2}$, and it is the fifth largest basin in Algeria, it is located between $36^{\circ} 11^{\prime}$ and $34^{\circ} 29^{\prime} \mathrm{N}$ latitude and between $3^{\circ} 2^{\prime}$ and $6^{\circ} 11^{\prime}$ E longitude (Figure 2). This basin straddles two 
distinct geological and geomorphological domains. To the north and northeast is the Tellian Atlas, and to the South, the Saharan Atlas. The situation of this basin between two series of mountains to the north and the south, organizes it as an endorheic basin around an almost flat bowl at $400 \mathrm{~m}$ altitude. At the center of this basin, the dry salt lake named "Chott El Hodna" covers around $1150 \mathrm{~km}^{2}$. This area receives the water and the sediment yields of the whole Wadis of the region [47].

The El Hodna watershed is characterized by a semi arid climate, with annual mean rainfall less than $200 \mathrm{~mm}$ per year and high temperatures in the summer and low in the winter [48]. The lowest temperature is reached during January with a value of $1.44{ }^{\circ} \mathrm{C}$, while the maximum is $37.92^{\circ} \mathrm{C}$ in August (Meteorological station of M'Sila from 1988 to 2014).

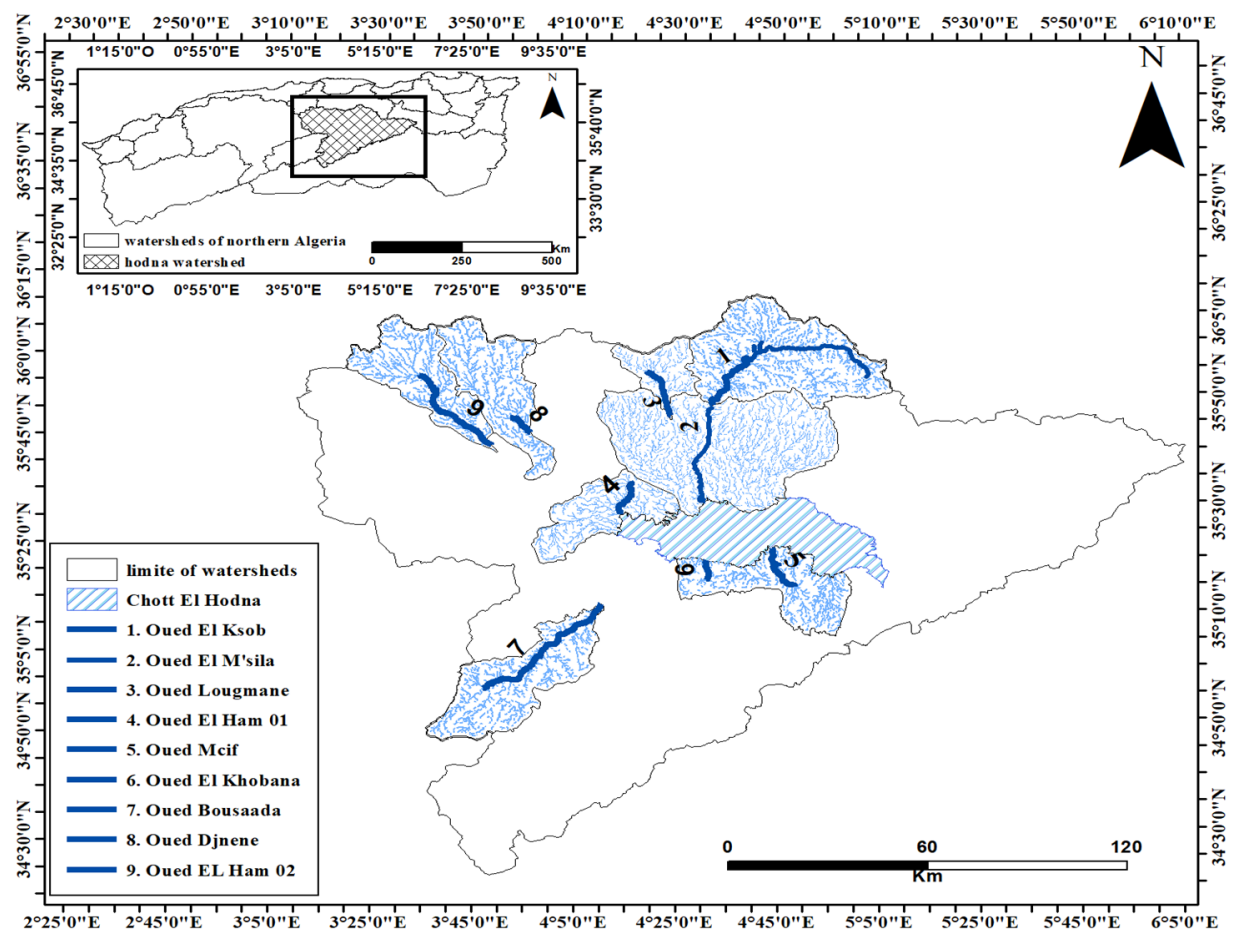

Figure 2. Situation of studied Wadis in El Hodna basin.

\section{Water sampling and analysis}

Nine Wadis of the Hodna basin are chosen as sampling sites, which they flow into Chott El Hodna. 
The water samples were collected during April 2018 by clean polyethylene bottles, where they rinsed thrice before sample collection. Parameters such as $\mathrm{pH}$, dissolved oxygen, temperature, salinity, conductivity and TDS were measured in situ by using a portable multiparameter. All samples are labeled properly after that they transported in cooler boxes at a temperature below $4 \mathrm{C}^{\circ}$ immediately to the laboratory for analysis of other physicochemical parameters. Biochemical oxygen demand $\left(\mathrm{BOD}_{5}\right)$ was measured using an OxiTop IS12. Chloride was measured using Mohr's method. TS was determined by the drying and the weighing method, while bicarbonate was detected by titration method using $0.01 \mathrm{~N}(\mathrm{HCl})$, Turbidity measured by Turbidimeter ( $\mathrm{HACH} 2100 \mathrm{~N})$. The total Calcium and magnesium hardness were analyzed by volumetric titration methods. Nitrates, nitrites, phosphates, and ammonium have been dosed by a flame spectrophotometer [49].

\section{Statistical Analysis}

ANOVA test was performed to search for a possible variation it was employed for each parameter and each Wadi.

Pearson's correlation coefficient was applied to calculate the relationship between various physicochemical parameters. Significance levels of tests were taken as $p<0.05$ and highly significant as $p<0.01$. Also, the Principal Component Analysis (PCA) biplot was employed to show tendencies or clustering patterns. All the statistical analyses were performed with SPSS statistical software (2012 version 18.0).

\section{Water quality index}

WQI is one of the most effective tools to monitor surface and ground water pollution. In the formulation of the water quality index the relative importance of the various parameters depends on the intended use of water [50].

WQI has been calculated to evaluate the water quality of Wadis the El Hodna basin through several steps of the weighted arithmetic index method given by [51]:

$$
W Q I=\sum Q_{i} W_{i} / \sum W_{i}
$$

where $Q i$ is the sub quality index of the $i^{\text {th }}$ parameter (or Qi is the quality rating scale of each parameter), $W$ is the weight unfit of each parameter, and $n$ is the number of parameters. 


\section{Calculation of $Q i$ : $\mathbf{Q}_{\mathbf{i}}=100\left[\left(\mathbf{V}_{\mathbf{i}}-\mathbf{V}_{\mathbf{0}} / \mathbf{S}_{\mathbf{i}}-\mathbf{V}_{0}\right)\right]$}

Where, $\mathrm{Vi}$ is the estimated concentration of $i^{\text {th }}$ parameter in the analyzed water, $V_{0}$ is the ideal value of this parameter in pure water, $V_{0}=0$ (except $\mathrm{pH}=7.0$ and $\mathrm{DO}=14.6 \mathrm{mg} / \mathrm{l}), \mathrm{S}_{\mathrm{i}}$ is the recommended standard value of $\mathrm{i}^{\text {th }}$ parameter.

\section{Calculation of Wi}

Calculation of unfit weight (Wi) for water quality parameters is inversely proportional to the recommended standards for the corresponding parameters.

$$
W_{i}=K / S_{i}
$$

Where, $(K)=$ the proportionality constant and it can also be calculated by using the following equation: $K=1 / \Sigma\left(1 / S_{i}\right)$

WQI has been classified into 5 classes, the water quality is rated between excellent, good, poor, very poor and unfit consumption when the value of the index lies between 0-25, 26-50, 51-75, 76-100 and >100, respectively (Table 4).

Table 4. Water Quality Index (WQI) range and status [50].

\begin{tabular}{|c|c|}
\hline Water Quality index & Water Quality Status \\
\hline $0-25$ & Excellent \\
$26-50$ & Good \\
$51-75$ & Poor \\
$76-100$ & Very poor \\
$>100$ & Unfit for Consumption \\
\hline
\end{tabular}

\section{ACKNOWLEDGMENTS}

We thank the technical staff of biology laboratory of M'Sila University for their help in water analyzing.

\section{REFERENCES}

1. R. Subramanian; R. Vidhya; V.N. Mariappan; Eco. Env. Cons., 2018, 24, S392S402.

2. S. Bhasin; A.N. Shukla; S. Shrivastava; U. Mishra; Haya: Saudi. J. Life Sci., 2016, 1, 51-64.

3. K. Brindha; R. Kavitha; Environ. Earth Sci., 2015, 73(9), 5383-5393.

4. Y. Ouyang; Wat. Res., 2005, 39(12), 2621-2635.

5. A.D. Smitha; P. Shivashankar; Int. Res. J. Enviro. Sci., 2013, 2(8), 59-65. 
6. S.G. Patil; S.G. Chonde; A.S. Jadhav; P.D. Raut; Res. J. Recent Sci., 2012, 1(2), $56-6$.

7. E.R. Salcedo-Sánchez; S.E.G. Hoyos; M.V.E. Alberich; M.M. Morales; Environ. Monit. Assess., 2016, 188 (10), 1-2.

8. N.C. Kankal; M.M. Indurkar; S.K. Gudadhe; S.R. Wate; Asian. J. Exp. Bio, Sci., 2012, 26(1), 39-48.

9. D. Tyagi; D.S. Malik; Int. J. Curr. Res. Life. Sci., 2018, 7(8), 1234-1239.

10. J.E.B. Zandagba; F.M. Adandedji; B.E. Lokonon; A. Chabi; O. Dan; D. Mama; Am. J. Environ. Sci. Eng., 2017, 1(4), 117-127.

11. A.E. Donald; U.A. Blessing; Int. J. Fish. Aquat. Stud., 2019, 7(1), 153-159.

12. Ş. Şener; E. Şener; A. Davraz; Sci. Total Environ., 2017, 584, 131-144.

13. A.D.G. Al-Afify; A.A. Othman; M.F. Ramadan; Rend. Lincei. Sci. Fis. Nat. 2018, 29(3), 725-736.

14. S. Bouaroudj; A. Menad; A. Bounamous; H. Ali-Khodja; A. Gherib; D.E. Weigel; H. Chenchouni; Chemosphere, 2019, 219, 76-88.

15. N. Bougherira; A. Hani; F. Toumi; N. Haied; L. Djabri; Hydrol. Sci. J., 2015, 62(8), 1290-130.

16. A. Toumi; A. Reggam; H. Alayat; M. Houhamdi; J. Mater. Environ. Sci., 2016, 7(1),139-147.

17. A. Reggam; H. Bouchelaghem; M. Houhamdi; J.Mater. Environ. Sci., 2015, 6(5), 1417-1425.

18. A. Bengherbia; F. Hamaidi; R. Zahraoui; M.S. Hamaidi; S. Megateli; Leban Sci J., 2014, 15(2),39-51.

19. S. Benrabah; H. Bousnoubra; N. Kherici; M. Cote; Rev. Sci. Technol., Synthese, 2013, 26, 30-39.

20. S.M. Ezzat; H.M. Mahdy; M.A. Abo-State; E.H. Abd El Stakour; M.A. ElBahnasawy; Middle-East. J. Sci. Res., 2012, 12(14), 413-423.

21. W.M.A.W.M Khalik; M.P. Abdullah; N.A. Amerudin; N. Padli; J. Mater. Environ. Sci., 2013, 4(4), 488-495.

22. F. Mimeche; M. Biche; A. Ruiz-Navarro; F.J. Oliva-Paterna; Limnetica., 2013, 32 (2), 391-404.

23. S. Acharya; S.K. Sharma; V. Khandegar; Poll.Res, 2018, 37(1), 209-22.

24. R. Bhutiani; F. Ahamad; V. Tyagi; K. Ram; Environ. Conserv. J.,2018, 19(1\& 2), 191-201.

25. Y.B. Gideon; F.B. Fatoye; J.I. Omada; Int. J. Sci. Technol., 2013, 2(12), 891899.

26. S. Sanyal; D.K. Paul; J. Appl. Nat. Sci, 2019, 11(2), 492-502.

27. W. Ayad; M. Kahoul; J. Mater. Environ. Sci, 7, 1288-1297.

28. O.S. Brraich; S.K. Saini; Int. J. Adv. Res., 2015, 3(12), 1498-1509.

29. V. Pradeep; C. Deepika; G. Urvi; S. Hitesh; Int. J. Res. Chem. Environ., 2012, 2(1), 105-111.

30. S. Saha; A. Mandal; D. Sahoo; Int. J. Fish. Aquat. Stud., 2017, 5(6), 23-27.

31. D.N. Saksena; R.K. Garg; R.J. Rao; J. Environ. Biol., 2008, 29(5),701-71.

32. K.K. Sharma; S. Kour; K. Sharma; Int. J. Appl. Res., 2017, 3(7), 686-691.

33. A.M. Abdel-Satar; J. Aquat. Res., 2005, 31(2),200-223. 
34. M.H. Abdo; Afr J. Biol. Sci., 2010, 6 (2), 143-158.

35. N. Chaib; B. Samraoui; Sécheresse, 2011; 22, 171-177.

36. H. Effendi, B. Romanto; Y. Wardiatno; Procedia. Environ. Sci., 2015, 24, 228-237.

37. R. Bhateria; D. Jain; Rev. Sustainable Water. Res. Manage, 2016, 2(2), 161-173.

38. A. Barakat; M. El Baghdadi; J. Rais; B. Aghezzaf; M. Slassi; Int. Soil. Water. Conserv. Res., 2016, 4, 284-292.

39. H. Jeong; J. Park; H. Kim; J. Chem., 2013, 1-9.

40. N.R. Ilavarasan; R. Ilangovan; P.R. Prasanna; J. Environ. Biol., 2016, 37, 14631472.

41. M. Jeyaraj; G. Nirmaladevi; P.N. Magudeswaran; Int. J. Res. Dev. Technol., 2014, 2(4), 1-4.

42. S.N. Brinis; A. Boudoukha; A.A. Hamel; LARHYSS J., 2015, 22, 123-137.

43. B. Desai; H. Desai; Int. J. Agric. Environ. Sci., 2018, 5(3), 53-65.

44. W.H.O.; Guidelines for drinking water quality' incorporating first addendum, $3 \mathrm{rd}$ ed.; Electronic version for the Web, 2006, [http://www.who.int/water sanitation healt $\mathrm{h} / \mathrm{dwq} / \mathrm{gdwq} 0$ 506.pdf]

45. R.S. Ayers; D.W. Westcot; Food, Agriculture Organization of the Unfited Nations (FAO), water quality for agriculture, irrigation and drainage, FAO, Rome, Paper No. 29. Rev1, M-56, 1994.

46. C.C. M.E. (Canadian Council of Ministers of the Environment); 2007. A protocol for the derivation of water quality guidelines for the protection of aquatic life. Winnipeg, Manitoba: Canadian Council of Ministers of the Environment, 2007, PP 37

47. F. Boudjemline; A. Semar; J. Wat. Land Dev., 2018, 36(1), 17-26.

48. E. Bensaci; S. Bendjama; S. Telli; S. Reguig; A. Zoubiri; M. Houhamdi; Int J Environ Water., 2014, 3, 61-68.

49. J. Rodier; B. Legube; N. Merlet; R. Brunet; L'analyse de l'eau, $9^{\text {th }}$ ed, Dunod, Paris, France, 2009, pp. 160.

50. C.S. Rao; B.S. Rao; A.V.L.N.S.H. Hariharan; N.M. Bharathi; Int. J. Appl. Bio Pharm. Tech., 2010, 1(1), 79-86.

51. R.M. Brown; N.J. McCleiland; R.A. Deininger; M.F. O'Connor; Poll. Res., 1972, 6, 787-797. 